\title{
firISGUC.ORG
}

"İȘ, GÜC̣" ENDÜSTRi iLIȘKiLERi VE INSAN KAYNAKLARI DERGisi

"IS, GUC" INDUSTRIAL RELATIONS AND HUMAN RESOURCES JOURNAL

\section{Basel Ve Hong Kong Sözleşmeleri Bağlamında Gemi Söküm Endüstrisi: Çevre, Sağlık ve Güvenlik Odaklı Bir Analiz}

Ship-Breaking Industry in The Context Of Basel And Hong Kong Conventions: An Environment, Health And SafetyBased Analysis

\section{Dr.Yasemin KAYA}

Uludağ Üniversitesi, İ̈BF, Kamu Yönetimi Bölümü

Ekim/October 2012, Cilt/Vol: 14, Say1/Num: 4, Page: 71-88

ISSN: 1303-2860, DOI: 10.4026/1303-2860.2012.0211.x

Makalenin on-line kopyasına erişmek için:

http://www.isguc.org/? $\mathrm{p}=$ article\&id $=493 \&$ vol $=14 \&$ num $=4 \& y e a r=2012$

To reach the on-line copy of article:

http://www.isguc.org/?p=article\&id=493\&vol=14\&num=4\&year=2012

Makale İçin İletişim/Correspondence to: 
(c) 2000- 2012

"İ̧̧üç̧" Endüstri İlişkileri ve İnsan Kaynakları Dergisi

"İşǚç" Industrial Relations and Human Resources Journal

Ekim/October 2012, Cilt/Vol: 14, Say1/Num: 4
ISSN: 1303-2860, Journal DOI: 10.4026/1303-2860

İş,Güç, Endüstri İlişkileri ve İnsan Kaynakları Dergisi, yılda dört kez yayınlanan hakemli, bilimsel elektronik dergidir. Çalışma hayatına ilişkin makalelere yer verilen derginin temel amacı, belirlenen alanda akademik gelişime ve paylaşıma katkıda bulunmaktadır.

İş, Güç, Endüstri İlişkileri ve İnsan Kaynakları Dergisi, 'Türkçe’ ve ‘İngilizce' olarak iki dilde makale yayınlanmaktadır.

Dergimiz İş,Güç ulusal ve uluslararası birçok indekste taranmaktadır. (Cabells Directory, Ebsco Socindex, Index Islamicus, Index Copernicus, Worldwide Political Science Abstracts, Sociological Abstract, Ulakbim Sosyal Bilimler Veritanı, Asos Index)

Editör/Editor-in-Chief

Aşkın Keser (Uludağ University)

Editör Yardımcılarn/Co-Editors

K.Ahmet Sevimli (Uludağ University)

Gözde Yilmaz (Marmara University)

Uygulama/Design

Yusuf Budak (Kocaeli Universtiy)

Tarandiğı Indeksler

ASOS INDEX

CABELLS DIRECTORY

EBSCO SOCINDEX

Index ISLAMICUS

Index COPERNICUS

Sociological Abstract

ULAKBIM Sosyal Bilimler

Veritanı

Worldwide Political Science

Abstracts

\author{
Yayın Kurulu / Editorial Board \\ Yrd.Doç.Dr.Zerrin Furat (Uludă̆ University) \\ Doç.Dr.Aşkın Keser (Uludağ University) \\ Prof.Dr.Ahmet Selamoğlu (Kocaeli University) \\ Yrd.Doç.Dr.Ahmet Sevimli (Uludağ University) \\ Doç.Dr.Abdulkadir Şenkal (Kocaeli University) \\ Doç.Dr.Gözde Yılmaz (Marmara University) \\ Dr.Memet Zencirkıran (Uludağ University)
}

Uluslararası Danışma Kurulu / International Advisory Board Prof.Dr.Ronald Burke (York University-Kanada)

Assoc.Prof.Dr.Glenn Dawes (James Cook University-Avustralya)

Prof.Dr.Jan Dul (Erasmus University-Hollanda)

Prof.Dr.Alev Efendioğlu (University of San Francisco-ABD)

Prof.Dr.Adrian Furnham (University College London-İngiltere)

Prof.Dr.Alan Geare (University of Otago- Yeni Zellanda)

Prof.Dr. Ricky Griffin (TAMU-Texas AEM University-ABD)

Assoc. Prof. Dr. Diana Lipinskiene (Kaunos University-Litvanya)

Prof.Dr.George Manning (Northern Kentucky University-ABD)

Prof. Dr. William (L.) Murray (University of San Francisco-ABD)

Prof.Dr.Mustafa Özbilgin (Bruner University-UK)

Assoc. Prof. Owen Stanley (James Cook University-Avustralya)

Prof.Dr.Işık Urla Zeytinoğlu (McMaster University-Kanada)

Ulusal Danışma Kurulu I National Advisory Board
Prof.Dr.Yusuf Alper (Uludă̆ University)
Prof.Dr.Veysel Bozkurt (İstanbul University)
Prof.Dr.Toker Dereli (Işık University)
Prof.Dr.Nihat Erdoğmuş (İstanbul Şehir University)
Prof.Dr.Ahmet Makal (Ankara University)
Prof.Dr.Ahmet Selamoğlu (Kocaeli University)
Prof.Dr.Nadir Suğur (Anadolu University)
Prof.Dr.Nursel Telman (Maltepe University)
Prof.Dr.Cavide Uyargil (İstanbul University)
Prof.Dr.Engin Yildırım (Anayasa Mahkemesi)
Doç.Dr.Arzu Wasti (Sabancı University)

Dergide yayınlanan yazılardaki görüşler ve bu konudaki sorumluluk yazarlarına aittir.

Yayınlanan eserlerde yer alan tüm içerik kaynak gösterilmeden kullanılamaz.

All the opinions written in articles are under responsibilities of the outhors.

The published contents in the articles cannot be used without being cited. 


\title{
Basel Ve Hong Kong Sözleşmeleri Bağlamında Gemi Söküm Endüstrisi: Çevre, Sağlık ve Güvenlik Odaklı Bir Analiz
}

\author{
Ship-Breaking Industry in The Context Of Basel And Hong Kong \\ Conventions: An Environment, Health And Safety-Based Analysis
}

\author{
Dr.Yasemin KAYA \\ Uludağ Üniversitesi, İ̈BF, Kamu Yönetimi Bölümü
}

\begin{abstract}
Özet
Çalışmanın amacı, gemi sökümü endüstrisindeki çevre, sağllk ve güvenlik şartlarımın iyileştirilmesi sorununa, Basel ve Hong Kong Sözleşmeleri'nin yanıt olabilme potansiyeli üzerine karşılaştırmalı bir analiz yapmaktır. Söz konusu düzenlemeler soruna etkin bir çözüm üretilme konusunda ciddi bir ikilemle karşı karşıyadır. Gemi söküm işlemi belirli standartlara uygun olarak gerçekleştirildiğinde ekonomik açıdan yapılabilir bir faaliyet olmaktan çımaktadır. Ancak diğer taraftan, dünya deniz filosu hacmindeki genişlemeye bağlı olarak sökümü ve geri dönüşümü gereken gemi miktarı giderek artmaktadır. Dolayısıyla ilgili düzenlemeler bir yandan bu işin ekonomik açıdan yapılabilir bir faaliyet olarak kalmasını, öte yandan da işçi sağglı̆̆ı ve güvenliği ile çevreye iliş̧kin şartların iyileştirilmesini sağlamahıdırlar. Doğal olarak bu ikilem, Sözleşmelerin gücünü ve etkinliğini zayıflatmaktadır. Gelişmiş ülkeler, yüksek maliyetler ve sektörün taşıdığı riskler sebebiyle gemi söküm işlemi yapmamakta ve hurda gemileri gelişmekte olan ülkelere ihraç etmektedir. Söküm işlemi yapılan gelişmekte olan ülkeler ise düşük standartların yarattığı maliyet avantajın kullanarak bu işten kazanç sağlamakta ancak bu süreçte sektörle bütünleşen ciddi çevre ve sağlık sorunlarına maruz kalmaktadır.
\end{abstract}

Anahtar Kelimeler: Gemi Sökümü, Basel Sözleşmesi, Hong Kong Sözleşmesi, İşçi Sağhlğı ve Güvenliği, Çevre.

\begin{abstract}
This study aims to make a comparative analysis on the Basel and Hong Kong conventions' potential to improve the conditions related to health, safety and environment in ship-breaking industry. These arrangements face a severe dilemma in producing an effective solution to the problem. Because of high standards and strict obligations, ship recycling process is not an economically viable activity. On the other side, the number of fleets has been increasing day by day in the world because of the rise in sea transportation. Thus these regulations should be made in order to keep the ship-breaking as an economically executable process on the one hand and to ameliorate the conditions related to worker's health and security, and environmental compliance on the other hand. Naturally, this situation weakened the strength and effectiveness of these conventions. The developed countries prefer not to make any shipbreaking because of the high costs and risks, and they export the scrap vessels to the developing states. Because of poor standards in developing states, ship-breaking can be executed less costly and they can profit from this industry, but they are exposed to severe environmental and health problems.
\end{abstract}

Key Worlds: Ship-breaking, Basel Convention, Hong Kong Convention, Occupational health and safety, Environment. 


\section{GiRiş}

Gemi sökümü, nispeten düşük düzeyde bir yatırım gerektirmesi, büyük ölçüde emek gücüne dayanması ve bu bağlamda önemli bir istihdam yaratması nedeniyle gelişmekte olan ülke ekonomileri için oldukça önemli bir sektördür. Ancak gemi sökümü, gelişmekte olan ülkelerdeki ilkel çalışma şartları ve etkin bir denetim mekanizmasının olmaması sebebiyle işçi sağlığı ve güvenliği ile çevre açısından ciddi bir risk oluşturmaktadır. Çevresel bilinç düzeyindeki artışa paralel olarak gelişmiş ülkelerde gemi sökümüne endişe ile yaklaşılması, bu alanda oldukça katı yasal düzenlemelerin oluşturulmasını sağlamıştır. Bu düzenlemeler söküm maliyetlerini önemli ölçüde artırarak, söz konusu sektörün daha düşük maliyetlerle söküm işlemini gerçekleştiren gelişmekte olan ülkelere kaymasına neden olmuştur (Neşer vd. 2008: 351).

Gelişmiş ülkelerde, ișçi sağlığ 1 ve güvenliği ile çevrenin korunmasına yönelik olarak oluşturulan standartların maliyetleri artırması, söküm işlemini ekonomik açıdan uygulanabilir bir faaliyet olmaktan çıkarmıştır (EC, 2007a: 5-6). Bu nedenle $A B$ ve OECD ülkelerinde 1970'lerden bu yana fiili anlamda söküm işlemi yapılmamaktadır. Yükselen maliyetler dolayısıyla $A B$ ve OECD ülkelerinde bulunan söküm tesislerinin faaliyetlerini durdurması, bu işleminin gerekli sağlık ve güvenlik şartlarının yokluğu nedeniyle maliyetlerin oldukça düşük olduğu Asya ülkelerine kaymasına neden olmuştur. Bugün gemi söküm işleminin tamamina yakına, Çin, Hindistan, Pakistan ve Bangladeş ülkelerinde yapılmaktadır. Bu ülkelere göre nispeten küçük miktarda da olsa, OECD ülkeleri arasında gemi sökümü yapan tek ülke ise Türkiye'dir (Lück, 2010: 98).

Söz konusu ülkelerdeki kötü çalışma koşulları, yaşanan iş kazaları ve çevresel bozulma uluslararası toplumun konuya yönelik ilgi ve kaygısını artırmış ve sektörün sürdürülebilir bir temel üzerine inşa edilmesini sağlamak amacıyla çeşitli yasal düzenlemeler ve teknik rehberler hazırlanmıştır. Bu kapsamda değerlendirilmesi gereken temel düzenlemeler ise 1989 yılında kabul edilen ve 1992 yılında yürürlüğe giren "Tehlikeli Atıkların Sınır Ötesi Taşınımı ve Bertarafına İlişkin Basel Sözleșmesi" ve 2009 yılında kabul edilen ancak henüz yürürlüğe girmeyen "Gemilerin Güvenli ve Çevreyle Duyarlı Geri Dönüşüne İlişkin Hong Kong Sözleşmesi"dir. ${ }^{1}$ Çalıșma, esas itibarıyla söz konusu düzenlemelerin gemi söküm sektöründeki koşulların gelişimine ne derece katkı sağladığ 1 ya da sağlayabileceği konusunda karşılaştırmalı bir analiz yapmayı amaçlanmaktadır. Bu amaç çerçevesinde öncellikle gemi söküm sektörüne ve sektörle bütünleşen sorunlara ilişkin genel bir değerlendirme yapılacak ve ardından Basel ve Hong Kong Sözleşmeleri'nin bu sorunlara yanit olabilme konusundaki etkinlikleri değerlendirilecektir.

\section{GEMI SÖKÜM ENDÜSTRISIINE BAKIŞ}

Uluslararası ticaretin yaklaşı \% 90'ının deniz yoluyla gerçekleştirilmesi ve artan deniz taşımacılığı nedeniyle dünya deniz filosu hacmi giderek artmaktadir. 2010 yılı ocak ayı verilerine göre kullanımda olan toplam ticari gemi sayıs 102.194 ve toplam tonajları 1,27 milyon dwt'dir. ${ }^{2} 2009-2010$ y1lları arasında dwt bazında artıș oranı ise ortalama \%7'dir (Unctad, 2010: 30). Dünya deniz filosunun önemli bir bölümünü ticari gemiler oluşturmakla birlikte, ticari amaçla kullanılmayan gemileri, savaş gemilerini ve devlet mülkiyetinde olan gemileri de dikkate aldığımızda toplam deniz filosu hacminin bu rakamların çok daha üstünde olduğunu tahmin etmek güç değildir. Diğer taraftan mevcut ticari gemilerin \% 56's1 yirmi yaşının üzerindedir ve ortalama gemi yaş1 23'dür (Unctad, 2010: 36). Bir geminin kullanımın ömrünün 20-30 yıl arasında olduğu düşünülürse, sökümü gereken ciddi miktarda geminin olduğu net bir şekilde görülmektedir. Bununla birlikte, 2010 yılından itibaren özellikle 1980'li yıllarda üretilen tek cidarlı gemilerin kullanımdan kalkmasına ilişkin IMO (Uluslararası Denizcilik Örgütü) kararının da söküme gidecek gemi miktarını 
önemli ölçüde artıracağ1 tahmin edilmektedir (CIEL, 2011: 11).

Gemi sökümü, asılında bir geri dönüşüm işlemi olduğundan, ekonomi çevrelerince yeşil endüstri olarak nitelendirilmektedir. Çünkü çelik üretiminde söküm işleminden kazanılan hurda demirin kullanılması, bu işlemde demir cevherinin kullanılmasina oranla daha az kaynak tüketimi sağlamakta ve daha az kirlilik üretmektedir. Ancak uygun şartlarda gerçekleştirilmeyen söküm işlemi çevre ve insan sağlığı üzerinde ciddi etkiler yaratmaktadır (DDK, 2008: 192). Bu durum gemi söküm sektörünün uzun yıllar çevre tahribatıyla ve iş kazalarıyla anılan bir sektör olmasına neden olmuştur.

Gemi sökümü aslında 1970'lere kadar Avrupa ve Amerika'da da görülen bir endüstriyel faaliyettir. Ancak 1970'lerde emek maliyetlerinin ve çevresel düzenlemelerin artması söküm endüstrisinin Tayvan ve Güney Kore'deki tersanelere taşınmasına neden olmuştur. 1980'lerde söz konusu ülkeler, sektöre olan ilgilerini kaybetmiș ve tesislerini gemi inşası amacıyla kullanmaya başlamışlardır. Bu dönemde Hindistan, Pakistan ve Bangladeşli girişimcilerin söküm maliyetlerini minimuma çeken, kıyıda ve elle söküm yöntemini kullanarak bu işten yüksek kazanç sağlama hevesleri pazarın yönünün Güney Asya ülkelerine çevrilmesine neden olmuştur (Neşer ve diğ., 2006: 351; CIEL, 2011: 12).

Avrupa Birliği ülkelerinde gemi sökümü, Güney Asya ülkeleriyle karşılaştırıldığında, işgücü maliyetleri, çevre ve sağlık standartları ve geri dönüştürülen materyalden elde edilecek gelirdeki faklılıklar sebebiyle ekonomik açıdan uygulanabilir değildir (Lück, 2010: 96). Avrupa Komisyonu tarafindan gemi sökümüne ilişkin olarak hazırlanan rapora göre Avrupa bayraklı gemilerin söküm işlemi Bangladeş, Hindistan ya da Pakistan'da yapıldığında gemi ağırlığına göre ton başına 380 USD gelir elde edilmektedir. Söküm işleminin, standartların bu ülkelere kıyasla daha yüksek olduğu Çin ya da Türkiye'de yapılması durumunda ise elde edi- lecek gelir 225 USD'dir. Buna karşın söküm işlemi $\mathrm{AB}$ ülkelerinde gerçekleştirildiği takdirde ton başına elde edilecek gelir - 20 ile 130 USD arasindadır (EC, 2007b: 11). K1sacası söküm işlemi belirli standartlar çerçevesinde yapıldığında pek de kazanç sağlamamaktadır. Diğer bir deyişle, gemi söküm sektörünün varlığı bir anlamda kötü çevre ve çalışma koşullarının devam ettirilebilmesine bağlıdır. Bu nedenle sektörün ekonomik getirisinden faydalanan devletler, bu alanda mevzuat oluşturmaya ve uygulanmasını sağlamaya pek de gönüllü değillerdir (Neşer ve diğ., 2006: 350).

Bugün gemi söküm işleminin yaklaşık \% 97'si Bangladeş, Çin, Hindistan, Pakistan ve Türkiye'nin oluşturduğu beş ülkede gerçekleştirilmektedir. Söküm yapan diğer 4 ülkenin kapasiteleriyle karşılaştırıldığında ( 7.7 MGT, 7.6 MGT, 6.8 MGT ve 2.1 MGT) Türkiye'nin söküm kapasitesi (0.6 MGT) oldukça düşüktür. Ancak Türkiye'nin söküm kapasitesi, dünyanın geri kalan ülkelerinin kapasiteleri toplamindan (0.4 MGT) daha fazladir. (Mikelis, 2010).

Ciddi miktarda gemi sökümü yapılan Güney Asya ülkelerinde çevre, sağlık ve güvenlik açısından gerekli asgari düzeydeki şartlar dahi karşılanmamaktadır (Moen 2008, 1053). Çevre ve güvenlik standartlarına uyumlu söküm kapasitesi ise dünya genelinde toplam söküm kapasitesinin \% 30'una denk gelmektedir. Bu tesislerin önemli bir bölümü Çin'dedir. Avrupa ülkelerinde yer alan tesisler ise yüksek maliyetler nedeniyle mevcut kapasitelerini kullanmamaktadırlar (EC, 2007a: 3). Çevreyle uyumlu söküm işleminin birincil şartı, geminin kuru havuz olarak ifade edilen özel alanlarda sökülmesidir. Çünkü geminin su, hava ve toprak gibi çevresel unsurlarla teması ancak bu yolla engellenebilir ve söküm işlemi kontrollü şekilde sağlanabilir (Neşer ve diğg., 2008: 356). Büyük gemilerin kuru havuzlarda sökümü ise gemilerin bu alanlara taşınmasındaki zorluk ve tesislerin ölçeği nedeniyle pek mümkün olmamaktadır. Bu nedenle söz konusu tesislerde genel olarak küçük gemi- 
Tablo 1

Ülkelere Göre Yıllık Gemi Söküm Miktarı (Ton) 2000-2009

\begin{tabular}{|c|c|c|c|c|c|c|c|c|c|}
\hline 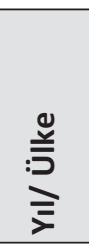 & 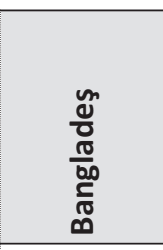 & 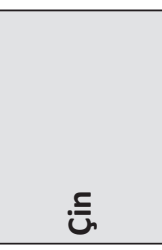 & 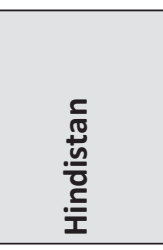 & 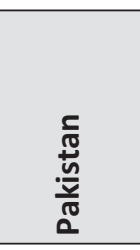 & 豙 & 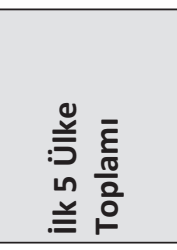 & 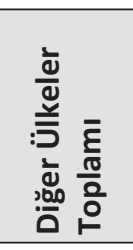 & 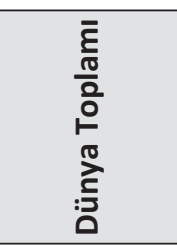 & 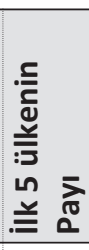 \\
\hline 2000 & 2.406 .923 & 2.637 .463 & 5.987 .392 & 789.216 & 294.541 & 12.115 .535 & 216.471 & 12.332 .006 & $\% 98$ \\
\hline 2001 & 4.992 .402 & 2.509 .792 & 4.767 .933 & $\begin{array}{c}1.738 .64 \\
0\end{array}$ & 164.728 & 14.173.495 & 121.986 & 14.295 .481 & $\% 99$ \\
\hline 2002 & 4.893 .973 & 3.138 .838 & 6.751 .349 & 997.236 & 385.437 & 16.166 .833 & 209.828 & 16.376 .661 & $\% 99$ \\
\hline 2003 & 2.889 .908 & 5.582 .476 & 5.886 .259 & 816.961 & 280.367 & 15.455 .971 & 472.221 & 15.928 .192 & $\% 97$ \\
\hline 2004 & 3.356 .537 & 1.538 .067 & 1.619 .505 & 209.055 & 200.183 & 6.923 .347 & 272.145 & 7.195 .492 & $\% 96$ \\
\hline 2005 & 2.113 .765 & 151.089 & 1.123 .487 & 47.530 & 137.693 & 3.573 .564 & 198.646 & 3.772 .210 & $\% 95$ \\
\hline 2006 & 2.882 .503 & 254.146 & 852.990 & 186.987 & 148.448 & 4.325 .074 & 266.571 & 4.591 .645 & $\% 94$ \\
\hline 2007 & 1.837 .988 & 340.738 & 1.332 .492 & 379.601 & 117.817 & 4.008 .636 & 144.211 & 4.152 .847 & $\% 97$ \\
\hline 2008 & 4.176 .026 & 927.762 & 2.458 .113 & 273.937 & 141.351 & 7.977.189 & 302.598 & 8.278 .787 & $\% 96$ \\
\hline 2009 & 6.608 .531 & 7.737.730 & 7.561 .258 & $\begin{array}{c}2.100 .63 \\
7\end{array}$ & 557.251 & 24.565 .407 & 393.113 & 24.958 .520 & $\% 97$ \\
\hline
\end{tabular}

Kaynak: Mikelis, 2010.

lerin sökümü yapılmaktadır. Kuru yük gemileri, savaş gemileri ve tankerler gibi büyük gemilerin sökümü ise genellikle k1yıda ya da iskelede yapılmaktadır (CIEL, 2011: 12).

Bangladeş, Hindistan ve Pakistan'da gemiler, gelgitle oluşan sı̆̆ su alanında, nehir ağzında ya da kıyıda sökülmektedir (Lück, 2010: 96; EC, 2008: 3). Çin de ise iskelede ya da gemi kızağında söküm yapılmaktadır. Türkiye'de ise gemiler, kısmi kızak olarak nitelendirilen ve geminin bir kısminin karaya oturtulması diğer kısmının ise suda kalmasını ifade eden bir yöntemle sökülmektedir (Çeviker, 2010; Neşer ve diğ., 2008: 352). Ancak kıyıda ya da iskele de yapılan söküm işlemlerinde denetim sağlanması çok zordur. Deniz kıyısında yapılan söküm işlemlerinde geminin çevreden yalıtımı sağlanamadığından ciddi miktarda kirleticinin havaya, suya ve toprağa karışması kaçınılmaz olmaktadır.

Gemi söküm işleminin çevre üzerindeki etkisi, gemilerin gövde ya da ekipmanlar1nın büyük oranda tehlikeli madde içermesinden kaynaklanmaktadır. Asbest, poliklorlu bifeniller (PCB), kurşun, kadmiyum, krom gibi ağır metaller, boya ve koru- 
yucu gibi kimyasallar, atık yağlar gibi çok sayıda tehlikeli madde söküm işlemi esnasinda çevreye yayılmakta ve ciddi bir risk oluşturmaktadır (Küçükgül ve Güneş, 2007:318). Gerek ulusal, gerekse uluslararası düzenlemelerce tehlikeli atık olarak kabul edilen ve yönetimleri katı standartlara bağlanan bu maddeler, gelişmekte olan ülkelerde gerekli altyapının olmaması sebebiyle doğrudan alıca ortama birakılmakta ve ciddi sorunlara yol açmaktadır. Bu nedenle gemi sökümü aynı zamanda bir tehlikeli atık yönetim işlemi olarak da görülebilir. Meseleye bu açıdan baktığımızda, söküm amacıyla hurda gemi ihracatı, aynı zamanda yasadışı bir faaliyet olan tehlikeli atık ihracatı anlamina gelmektedir.

Sektörün ciddi sorunlara neden olduğu bir diğer alan ise çevresel şartlardan ayrı düşünülemeyecek olan işçi sağlığ1 ve güvenliğidir. ILO (Uluslararası Çalışma Örgütü) tarafından ağır ve tehlikeli işler sınıfında değerlendirilen gemi sökümü, emek yoğun bir sektör olarak, işçi sağlı̆̆ 1 ve güvenliği aç1sından büyük risk taşımaktadır. Yangın, patlama, yüksek oranda kirleticiye maruz kalma, radyasyon, gürültü gibi pek çok sorun işçi sağllğ 1 ve güvenliğini tehdit etmektedir (Christensen, 2010). Sektöre ilişkin olarak hazırlanan ülke raporlarının hemen hepsi, gemi sökümü yapılan alanlarda ciddi sorunlar olduğunu ortaya koymaktadır. Örneğin Hindistan hükümeti tarafından hazırlanan raporda, Hindistan'daki en büyük söküm alanı olan Alang'da her altı işçiden birinin asbeste maruz kalma dolayısıyla çeşitli sağlık sorunları yaşadığ dir. Hindistan'da gemi söküm sektöründe ölümle sonuçlanan kazaların oranı madencilik endüstrisinden 6 kat fazladır. Söz konusu rapora göre, 1996-2003 yılları arasinda Alang bölgesinde yaşanan 434 kazada 209 işçi hayatını kaybetmiştir. Bangladeş'e ilişkin olarak hazırlanan raporlarda ise geçen 20 y1l içinde söküm alanında çalışan 400 işçinin hayatını kaybettiği ve 6.000 işçinin de yaralandığ1 belirlenmiştir (EC, 2007a:2,8). . Türkiye'deki tek gemi söküm alanı olan Aliağa bölgesine ilişkin olarak 2000-2007 yılları arası yapılan araştırmalarda ise bölgede işçi sağlığ́1 ve güvenliği ile çevreye ilişkin son derece ciddi problemler tespit etmiştir. ${ }^{4}$ Aliağa bölgesinde 1990-2005 y1lları arasında gerçekleşen 23 kazada toplam 29 kişi hayatını kaybetmiştir (Öztürk, 2010). 01.10.200702.11.2007 tarihleri arasında Çalışma ve sosyal güvenlik Bakanlığı tarafından gerçekleştirilen Gemi Sökümü Yapılan İşyerlerinde İş Sağlığ1 ve Güvenliği Proje Denetimi raporuna göre, söküm bölgesinde çalışan işçilerin \% 85'i Ağır ve Tehlikeli İşler Yönetmeliği kapsamındaki işlerde çalışmaktadır (ÇSGB, 2007).

ILO raporlarında ise söküm yapılan alanlara ilişkin olarak dikkat çekilen temel sorunlar şunlardır:

- İşçilerin çoğu vasıfsızdır ve işin gerektirdiği teknik bilgi ve beceriye sahip değildir.

- İşçilerin büyük bir kısmı geçici sürelerle istihdam edilmektedir ve iş sözleşmeleri yoktur.

- Kaza ve yaralanmalara karşı yeterli denetim alınmamıştır.

- Çalışma saatleri uzun, ücretler düşüktür. $^{5}$

- İşçi sağll̆̆ 1 ve güveliğine ilişkin denetim sağlanmamiştır.

- İşçilere sağlık ve güvenlik konularında gereken eğitim verilmemektedir.

- Acil, ilk yardım ve kurtarma hizmetleri yetersizdir.

- Sağllk görevlisi, hekim, iş güvenliğinden sorumlu mühendis veya teknik eleman gibi uzman personel istihdamı yetersizidir (ILO, 2003:2-5; Andersen, 2001:4-5; Christensen, 2010).

Sektörle bütünleşen sorunların giderek daha fazla farkına varılması, söküm alanlarında yaşanan kazalar karşısında kamuoyunun artan tepkisi ve Sivil Toplum Kuruluşlarının baskısı söküm işleminin çevre, sağlık ve güvenlik şartlarına uygun gerçekleştirilmesini sağlamaya yönelik ulus- 
lararası çabaları artırmıştır. Bu konuda IMO, ILO ve Basel Sözleşmesi Sekretaryası tarafından hazırlanan ve gemi söküm işleminin belirli standartlar çerçevesinde gerçekleştirilmesini amaçlayan rehber ve kılavuzlar önemli bir gelişmedir. ${ }^{6}$ Ancak yasal açıdan bağlayıcı nitelik taşımayan bu dokümanlar, bu alanda faaliyet gösteren işletmelerin eylemlerinde ciddi bir değişim yaratacak güce sahip değildirler. Bu belgelerde yer alan ilke ve kurallar ulusal yasalara yansımadikça pek de uygulama alanı bulamamaktadır. Sektörde belirli değişimlere vesile olabilecek, hukuki bağlayıcılığ 1 sahip ve uluslararası nitelik taşıyan iki temel düzenleme bulunmaktadır. Bunlar 1992 tarihli "Tehlikeli Atıkların Sınır Ötesi Taşınımı ve Bertarafına İlişkin Basel Sözleşmesi” ve 2009 tarihli “Gemilerin Güvenli ve Çevreye Duyarlı Geri Dönüşümüne İlişkin Hong Kong Sözleşmesi"dir.

\section{BASEL SÖZLEŞMESi}

Tehlikeli atıkların yönetimine ilişkin küresel çapta en kapsamlı düzenleme olan Basel Sözleşmesi 22 Mart 1989 yılında benimsenmiş ve 1992 yılında yürürlüğe girmiştir. 178 ülkenin taraf olduğu Sözleşme, tehlikeli ve diğer atıkların üretimi, yönetimi, sınır ötesi hareketi ve bertarafından kaynaklanacak zararlı etkilere karşı insan sağlığ 1 ve çevreyi korumayı amaçlamaktadır (SBC, 2008:1). Bu amacin gerçekleştirilmesine yönelik olarak Basel Sözleşmesi'nin faaliyet alanı, dört başlık çerçevesinde ele alınabilir. Bunlar; tehlikeli atık üretiminin azaltılması, tehlikeli atıkların çevreye duyarlı yönetiminin desteklenmesi, tehlikeli atıkların mümkün olduğu ölçüde üretildiği yere en yakın mesafede bertarafının sağlanması ve tehlikeli atıkların sınır ötesi hareketinin denetlenmesi ve azaltılmasıdır (Sand 1992: 328).

Basel Sözleşmesi'nin oluşturulmasına temel teşkil eden asıl sorun atıkların gelişmiş ülkelerden gelişmekte olan ülkelere transferini önlemektir. Bu nedenle Sözleşme metninin esas itibariyle bu sorun bağlamında şekillendiği söylenebilir. Basel Sözleşmesi atıkların sınırötesi hareketini denetim altına almak ve özellikle gelişmiş ülkelerden gelişmekte olan ülkelere tehlikeli atık ihracını önlemek amacıyla bir dizi koruma ölçütü getirmektedir. Sözleşme'nin uluslararası atık ticaretine ilişkin olarak oluşturduğu rejim, atık transferinin yasaklandiğ 1 durumlar ve atık ticaretinin yazılı izne bağlı olduğu durumlar şeklinde ikili bir ayrım çerçevesinde değerlendirilebilir. Basel Sözleşmesi bazı durumlarda atık transferini ilkece yasaklamıştır. Diğer durumlarda ise atık transferi "ön bildirimli rıza" prosedürüne dayalı olarak kontrollü bir şekilde gerçekleştirilmektedir. Sözleşme'nin Genel Yükümlülükler başlıklı 4. maddesine göre atık transferinin yasak olduğu durumlar şunlardır:

- Tehlikeli ve diğer atıkların ithalini yasaklamış olan tarafa bu atıkların ihracı yasaktır. ${ }^{7}$

- Tehlikeli ve diğer atıkların çevresel açıdan güvenli yönetimini sağlayamayacak olan taraflara bu atıkların ihracı yasaktır.

- Taraf devletlerle taraf olmayan devletler arasında atık ticareti yasaktır.

- Tehlikeli ve diğer atıkların 60 derece güney enleminin güneyindeki bölgelere bertaraf amacıyla gönderimi yasaktır.

Sözleşme'ye göre, tehlikeli atıkların ihracatına ancak ihracatçı devletin atıkların bertarafını çevresel açıdan güvenli şekilde yapacak teknik kapasiteye ve uzmana sahip olmaması durumunda ya da atıklara ithalatçı devletin geri dönüşüm veya geri kazanım için hammadde olarak ihtiyaç duyması halinde izin verilebilir (BS, mad. 4/9a ve $4 / 9 b$ ). Bu durumda atık transferi sözleşmenin 6. maddesinde tanımlanan ön bildirimli rıza prosedürüne göre gerçekleştirilir. Sözleşme hükümlerine aykırı şekilde gerçekleştirilen atık transferi ise yasadışı olarak nitelendirilmektedir.

Ön bildirimli rıza prosedürü, Basel Sözleşmesi'nin oluşturduğu kontrol rejiminin temelini oluşturmaktadır ve taraflar arasın- 
daki atık ticareti bu prosedüre göre gerçekleştirilmektedir. Bu prosedüre göre, ihracatçı devlet tehlikeli atıkların ve diğer atıkların öngörülen sınır ötesi taşınımını, ithalatçı ve transit devletlere bildirmek zorundadır. Bu bilgi, öngörülen sınır ötesi taşınımın niteliği ve risklerini ithalatçı ve transit devletlerin yetkili otoritelerinin değerlendirmesini sağlayacak düzeyde detaylı olmalıdır. İthalatçı devlet, söz konusu taşınıma şartlı veya şartsız olarak rıza gösterdiğini, izin vermeyi reddettiğini veya ek bilgi istediğini belirten yazılı cevabını bildirimde bulunan tarafa gönderecektir. İthalatçı devlet cevabında, ihracatçı ile bertarafçı arasında atıkların çevreye duyarlı bir şekilde yönetimine ilişkin bir kontrat yapıldığını teyit etmelidir. Ayrıca tehlikeli atıkların veya diğer atıkların sınır ötesi taşınımı, Sözleşme'ye taraf olan ithalatçı devlet veya transit devletin gerekli göreceği sigorta, teminat veya başka bir garantiye tâbi olacaktır (BS, mad. 6/1-6/4 ve 6/11).

Aslına bakılırsa bu düzenleme oldukça detaylıdır. Buna rağmen bazı boşluklar uygulama açısından sorun yaratabilmektedir. Örneğin, ihracatçı devletin, ithalatçı ve bertarafçı arasında yapılan atıkların çevresel açıdan güvenli yönetimine dair kontratın içeriğini teyit etmeye dair herhangi bir yükümlülüğü yoktur. Sınır ötesi eylem söz konusu akdin mevcudiyetinin teyit edilmesi ile başlayabilir. Bu da gerçek anlamda atıkların çevresel açıdan güvenli yönetiminin sağlanıp sağlanamayacağını belirsiz bırakmaktadır. Ayrıca 'çevresel açıdan güvenli yönetim' kavramı Sözleşme içinde açık şekilde tanımlanmadığı için akdin içeriğinin ne olması gerektiği konusunda da bir netlik yoktur (Kummer 1992:548) ${ }^{8}$.

Basel Sözleşmesi'nin yürürlüğe girişinden buyana, tehlikeli atıkların sınır ötesi hareketine daha fazla sinırlama getirilmesine dair tartışmalar gündemden hiç düşmemiştir (Lawrence 1998:249). Atık ticareti, ekonomik ve politik açıdan hassas bir mesele olduğundan Sözleşme metninde bölgesel ya da küresel nitelikte bir ticaret yasağına yer verilmemiş ve 'ön bildirimli rıza' prosedürü aslında bir uzlaşı çözümü olarak oluşturulmuştur. Bu konuda daha güçlü sınırlamalar getirilmesi yönündeki baskının bir sonucu olarak, 1995'de gerçekleştirilen 3. Taraflar Konferansı'nda Sözleșme'nin atık transferine ilişkin bir yasak hükmü içerecek şekilde değiştirilmesi kararı alınmıştır (SBC, 1995). Basel Yasağı olarak bilinen değişiklik uyarinca, OECD ülkelerinden OECD dişı ülkelere tehlikeli atıkların bertaraf ya da geri dönüşüm amacıyla gönderimi yasaklanmıştır. Yasak değişikliği henüz yürürlüğe girmemiş olmakla birlikte, Sözleşme'nin ortaya çıkış amacı olan, güney ülkelerinin atık transferinden kaynaklanan mağduriyetlerinin önlemesi konusunda atılmış en önemli adımdır.

Basel Sözleşmesi atıkların yönetimi ve sınır ötesi hareketine ilişkin bir sözleşme olduğundan, ilk bakışta hurda gemiler ile bu gemilerin söküm işlemine ilişkin sorunları kapsamaya uygun bir düzenleme olarak düşünülmeyebilir. Gerçekten de Basel Sözleşmesi'nin orijinal metninde bu soruna ilişkin bir hüküm yer almamaktadır. Ancak gemilerin gövde ve ekipmanlarının ciddi miktarda tehlikeli atık içermesi, konun Basel Sözleşmesi kapsamında değerlendirilmesi gereğini ortaya çıkarmıştır. Zira tehlikeli atık ticareti, sadece gemilerin yük olarak taşıdığ atıkların bir ülkeden bir başka ülkeye transferi sonucu ortaya çıkmamaktadır. Bizatihi geminin kendisi de ciddi miktarda tehlikeli atık içermektedir. Bu nedenle gemi sökümüne yönelik ticaretin de tehlikeli atık ticareti kapsamında değerlendirilmesi gerekmektedir (Moen, 2008:1054; Lück, 2010:98).

Gemi sökümü sorunu aslında IMO önderliğinde hazırlanan Hong Kong Sözleşmesi bağlamında ele alınan bir sorundur. Ancak ilgili anlaşmanın 2015 yılından önce yürürlüğe girmesi beklenmemektedir. İlgili Sözleşme yürürlüğe girene kadar IMO ve Basel Sözleşmesi Sekretaryası arasında yap1lan anlaşma gereğince sorunun Basel Sözleşmesi kapsamında değerlendirilmesine 
karar verilmiştir. Bu çerçevede 2002 yılında Basel Sözleşmesi Sekretaryası tarafından “ Gemilerin Tam ve Kısmi Sökümünün Çevreye Duyarlı Yönetimine İlişkin Teknik Rehber" yayınlanmıştır. Söz konusu teknik rehberde söküm işleminin sebep olacağ riskleri elimine etmek için gemilerin ancak tam yalıtımın sağlandığı kuru havuzlarda sökülmesi gerektiği belirtilmiştir. Bir söküm metodu olarak kıyada söküm işlemine rehberde yer verilmemiştir. 2004 yılında Cenevre'de yapilan 7.Taraflar Konferansı'nda ise gemi sökümü ile ilgili önemli kararlar alınmıştır. Bunların en önemlisi hurdaya ç1kartılan gemilerin atık kabul edilerek Basel Sözleşmesi kapsamına alınması ve ön bildirimli rıza prosedürüne tabi olmasıdır (SBC, 2004). Taraflar Konferansı'nda alınan kararlarda söküm amaciyla hurda gemi ithal etmek isteyen gemi sahiplerinin veya ülkelerin,

- Gemilerini gönderdikleri ülkeye geminin yapısında ne tür tehlikeli maddeler kullanıldığını bildirmekle ve söküm için izin istemekle,

- Gemilerini mümkün olduğunca tehlikeli maddelerden arındırmakla ve

- Gemilerin çevreye duyarlı tesislerde sökülmesini garanti altına almakla yükümlü olmaları gerektiği belirtilmiştir (Vardar 2004: 323-324; Neşer 2008:353, 358).

Ancak geri dönüşüm amacıyla hurda gemi ticaretine Basel Sözleşmesi hükümlerinin uygulanıp uygulanmayacağı, Taraflar Konferansı'nda alınan kararların yasal statüsüne ilişkin tartışmalar nedeniyle net değildir. Aslında gemilerin bünyesinde yer alan tehlikeli atıklar Basel Sözleşmesi'nin kontrol rejimine tabi olan tehlikeli atık listelerinde yer almaktadır. Ancak gemilerin atık olarak kabul edilmesi, yasal açıdan tartışmalı bir kondur (CIEL, 2011:16). Bununlar birlikte devletler, Taraflar Konferansı'nda alınana karar doğrultusunda kendi yasal düzenlemelerini oluşturarak, Basel Sözleşmesi'nin bu alanda uygulanmasını sağlayabilir.

\section{HONG KONG SÖZLEŞMESİ}

IMO önderliğinde hazırlanan "Gemilerin Güvenli ve Çevreye Duyarlı Geri Dönüşümüne İlişkin Hong Kong Sözleşmesi", 19 Mayıs 2009 tarihinde 63 ülkenin katılımıyla gerçekleşen uluslararası konferansta kabul edilmiştir. Sözleşme'nin amacı, gemi geri dönüşüm işletmelerinde işçi sağlığını korumak ve gemi söküm alanlarındaki faaliyetlerin neden olduğu çevresel bozulma ve kirliliği engellemektir. Hong Kong Sözleşmesi, gemi sökümü kavramı yerine gemilerin geri dönüşümü kavramını kullanmakta ve ekonomik ömrünü dolduran gemiler için atık ya da tehlikeli atık türünden bir nitelemeye yer vermemektedir. Bu yönüyle Sözleşme'nin sorunun ekonomik boyutunu ön plana çıkaran bir yaklaşım sergilediği söylenebilir. Sözleşme geri dönüşümü, kullanım ömrü sona eren gemiler için en iyi çözüm yolu görmekte ve Sözleşme'nin önsözünde geri dönüşüm işlemi ile sürdürülebilir kalkınma arasındaki bağlantıya açık şekilde yer verilmektedir. Ancak unutulmaması gereken nokta, söz konusu işlemin bu konuda en iyi çözüm yolu olabilmesi için sürdürülebilirliğin çevresel ve sosyal boyutlarına da katkı sağlaması gerektiğidir (Lück, 2010: 97).

Bu açıdan Sözleşme'nin aslında bütünsel bir yaklaşım benimsediği söylenebilir. Çünkü Sözleşme'de yer alan gemilere, geri dönüşüm tesislerine, işçi sağlığ1 ve güvenliğine ve çevresel korumaya ilişkin hükümler, Sözleşme hazırlanırken sorunun tüm yönlerinin dikkate alınmaya çalışıldığını göstermektedir. Ancak Sözleşme genel itibariyle bazı uygulamaların yasaklanması gibi esasa ilişkin bir takım yükümlüklerden ziyade sertifika ve lisans gibi prosedürel yükümlülüklere ağırlık vermektedir ve bu yönüyle özelikle STK'lar tarafından eleştirilmektedir. (Lück, 2010: 95,99)

Hong Kong Sözleşmesi, yeni inşa edilecek gemilere, halen kullanımda olan gemilere ve kullanım ömrü sona eren gemilere yönelik şartlar içermektedir. Ancak Sözleşme, 500 gross tondan küçük gemileri, savaş ve donanma gemileri gibi devlet mül- 
kiyetinde olan ve ticari amaçlarla kullanılmayan gemileri kapsamamaktadır (HKS, mad.3/2-3). Hong Kong Sözleşmesi, "beşikten mezra" olarak da ifade edilen, geminin tasarlanmasından, inşasına, işletilmesine ve geri dönüşümüne kadar tüm aşamaları kapsayan bir uygulama ve kontrol sistemi öngörmektedir (EC, 2010:2). Bu sisteme göre yeni inşa edilecek gemilerde tehlikeli madde kullanımı yasaklanmıştır. Bu yasak mevcut gemilerin bakım ve onarımı için de geçerlidir. Ayrıca tüm gemilerin bünyelerinde barındırdıkları tehlikeli maddelere ilişkin olarak tehlikeli madde envanteri belgesine sahip olmaları gerekmektedir. "Yeşil Pasaport" olarak da ifade edilen bu belgenin, gemi kullanımda olduğu müddetçe ona eşlik etmesi ve her bakım/onarım işleminden sonra güncellenmesi gerekmektedir (Mikelis, 2010).

Bununla birlikte Sözleşme metninde gemi söküm işlemine ilişkin olarak özel standartlar belirlenmemiştir. Örneğin söküm işleminin tam yalıtımin sağlandığ1 kuru havuzlarda yapılması, tehlikeli atıkların güvenli şekilde muhafazası için uygun atık kabul noktalarının oluşturulması gibi hususlar Sözleşme'de yer almamaktadır. Sözleşme genel olarak ana amaç ve prosedürleri tanımlamakta ve teknik detaylar Sözleşme'nin eklerinde ele alınmaktadır. Ancak buradaki temel problem Sözleşme eklerinin de belirsiz olmasıdır. Tehlikeli madde envanteri, inceleme, sertifikasyon ve lisans gibi konular nispeten açıktır. Ancak gemi geri dönüşüm tesislerindeki faaliyetlerle ilgili olarak, çalışanlar için sağlık ve güvenlik riski oluşturmamak, çevre üzerindeki olumsuz etkileri engellemek gibi genel ifadeler yer almaktadır (HKS, Reg. 19-22; Lück, 2010:100).

Sözleşeme hükümlerine göre taraf bir devletin bayrağını taşıyan gemiler, ancak taraf devletlere ait olan tesislerde geri dönüştürülebilirler. Bu hüküm, tersi durum için de geçerlidir. Yani Sözleşme'ye taraf olan devletlerin geri dönüşüm tesislerinde ancak Sözleşme'ye taraf devletlerin bayrağını taşıyan gemiler kabul edilir. Taraf devletler kendi bayraklarını taşıyan gemilerin Sözleşme hükümlerine uygunluğunu denetleyerek sertifikalandırmalıdır. Aynı şekilde taraf devletler de kendi yetki alanları dahilinde faaliyet gösteren tesislere Sözleşeme hükümlerine uygun olarak geri dönüşüm yetki belgesi ya da lisansi vermeleri gerekmektedir (HKS, mad.5-6; Mikelis, 2010). Sertifikalı bir geminin, lisanslı bir tesiste geri dönüştürülmesine ilişkin prosedür ise şu şekilde işlemektedir:

- Gemi sahibi öncellikle gemide bulunan tehlikeli maddelerin tipini ve miktarını dikkate alarak geminin geri dönüşüm amacıyla gönderileceği lisanslı bir geri dönüşüm tesisi belirler. İlgili tesise gemiye ilişkin tüm bilgelerin bir kopyasını gönderir ve bayrak sahibi devlete geri dönüşüm amacıyla gemiyi ihraç etme niyetini bildirir.

- Geri dönüşüm tesisi gemiye ait bilgileri dikkate alarak, söz konusu gemi için geri dönüşüm planı hazırlar ve geminin deri dönüşüm amacıyla ithaline ilişkin olarak kendi yetkili otoritesine bildirimde bulunur. Bu bildirim, gemi sahibi ve şirketine, bayrak devlete ve gemiye ilişkin bilgileri içermelidir. Ayrıca tehlikeli atık envanteri ile taslak gemi geri dönüşüm planı da bildirime eklenmelidir.

- Yetkili otorite tarafından bildirimin onaylanmasıyla birlikte gemi, bayrağını taşıdığ 1 devlet tarafından son incelemeden geçirilir ve bu inceleme sonucunda gemiye geri dönüşüm için hazır olduğuna dair bir sertifika verilir. Sertifikanın alınmasıyla birlikte geri dönüşüm tesisi, yetkili otoritesine sertifikanın bir kopyası ile birlikte geri dönüşüm işlemine başlayacağını bildirir. Bu bildirimden önce geri dönüşüm işlemine başlanamaz.

- Söküm işlemi tamamlandığında, geri dönüşüm tesisi, yetkili otoritesine işin tamamlandığına ilişkin bir bildirimde bulur. Yetkili otorite bu bildirimin kop- 
yasını, geri dönüşüm sertifikasını veren idareye iletir (HKS, Reg. 8-9; Mikelis, 2010, EC, 2010: 3).

Bu prosedür aslında Basel Sözleşmesi'nin ön bildirim ve rızaya dayalı prosedüründen bir geriye gidiş olarak görülebilir. Çünkü bu prosedürde devletten devlete bildirim yoktur. Bildirimler bayrak devlet ile gemi sahibi ve geri dönüşüm tesisi ile yetkili otoritesi arasında gerçekleştirilmektedir. Bayrak devletin geri dönüşümün yapılacağa devlete bildirimi ön görülmemiştir. Ayrıca transit devletlere bildirimde bulunmaya ilişkin de bir hüküm bulunmamaktadır. Nihayetinde geri dönüşümün yapılacağı devletin ya da transit devletin rızasına olan ihtiyaca ilişkin bir vurgu da yoktur (Bhattacharjee, 2009:223). Aslında Hong Kong Sözleşmesi Basel Sözleşmesi'nin gemi sökümü alanındaki yetersizliklerini ve uygulamadaki boşlukları aşmak amacıyla oluşturulmuş bir düzenlemedir. Buna rağmen Sözleşme, gerek atıkların çevreye duyarlı yönetimini sağlamada, gerek bu gemilerin sağlık, güvenlik ve çevresel koşullar açısından yeterli kapasiteye sahip olmayan ülkelere gönderimi engellemede, gerekse bu ticaretin kontrollü şekilde gerçekleştirilmesini sağlamada Basel Sözleşmesi'ne göre yetersiz kalmaktadir.

\section{SÖZLEŞMELERIN GEMI SÖKÜMÜ ALANINDAKİ ETKINLIIKLERI}

Bilindiği üzere bir anlaşmanın etkinliği, yani ele aldığı sorunu çözmedeki başarısı, anlaşmanın yapısı ile taraf devletlerin anlaşmayı uygulamaya ilişkin istek ve kapasitelerinin bir fonksiyonudur. Anlaşmanın yapısına ilişkin belirleyici bir unsur, anlaşmanın ele alınan probleme yanıt olacak şartlar içermesidir. Bununun için problemin net bir şekilde tanımlanması ve problemi ortaya çıkaran nedenlerin doğru şekilde saptanması gerekmektedir. Anlaşmanın yapısına ilişkin bir diğer önemli husus ise anlaşma hükümlülerinin ne derece açı ve kararlı olduğudur. Anlaşmada taraf devletlerin yükümlülükleri açık ve net bir biçimde ortaya konmalıdır. Ayrıca bu yükümlülükler tavsiye niteliğindeki genel çağrılardan ziyade, sorunun çözümüne yönelik daha karalı hükümlerden oluşmalıdır. Bunun yanı sıra anlaşmanın tarafların uyum kapasitelerini artıracak finansal ve teknik destek mekanizmalarına, tarafların anlaşmaya uyumunu sağlamaya yönelik izleme ve denetleme mekanizmalarına sahip olması, etkili ceza ve yaptırımlar öngörmesi de anlaşmanın etkinliği açısından önemlidir (Jacobson and Weiss, 1997: 95-97; Wettestad, 1999: 9-10; Young and Demko, 1996: 230-234).

Anlaşmanın yapısına ilişkin bu genel çerçeveden hareketle, Basel ve Hong Kong Sözleşmeleri'nin yapıları itibariyle etkin düzenlemeler olup olmadıklarını değerlendirdiğimizde, söyleyebileceğimiz ilk şey, her iki Sözleşme'nin de gemi söküm sektörüyle bütünleşen sorunları çözebilecek yetkinlikte olmadığıdır. Öncellikle Basel Sözleşmesi tehlikeli atıkların sınır ötesi taşımı soruna ilişkin bir düzenleme olduğundan, gemi sökümüne uygulanması konusunda bir takım problemler bulunmaktadır. Bir kere söküm amacıyla gönderilen gemilerin atık kabul edilerek, Basel Sözleşmesi'nin öngördüğü prosedüre tabi tutulması yasıl açıdan belirsiz bir konudur. Basel Sözleşmesi 7. Taraflar Konferansı'nda hurda gemilerin atık kabul edilerek, Basel Sözleşmesi'nin kontrol rejimine tabi tutulması kararı alınmıştır. Ancak Taraflar Konferansı'nda alınan kararların yasal statüsü net değildir. Bu konu büyük ölçüde taraf devletlerin kendi inisiyatifine b1rakılmıştır. Taraflar istedikleri takdirde, Basel Sözleşmesi'nin ilgili hükümlerini dayanak alarak, hurda gemileri atık kabul ederek ülkelerine girişini yasaklayabilirler ya da kontrole tabi tutabilirler. Bununla birlikte gemi geri dönüşüm işlemi yapan beş ülkenin hepsi Basel Sözleşmesine taraf olmasina rağmen, sadece Türkiye hurda gemilerin ithalatında Basel Sözleşmesi'nin ön bildirimli rıza prosedürünü uygulamaktadır (EC, 2008:4). ${ }^{9}$

Hong Kong Sözleşmesi ise içerdiği şartlar itibariyle soruna çözüm oluşturmaktan zi- 
yade endüstrinin önünü açan ve mevcut uygulamaları meşrulaştıran bir nitelik taş1maktadır. Bilindiği üzere Basel Sözleşmesi, Avrupa bayraklı gemilerin gelişmekte olan ülkelerde sökümünü engellemektedir. Avrupa Birliği ülkeleri, OECD ülkelerinden OECD dişı ülkelere tehlikeli atıkların bertaraf ya da geri dönüşüm amacıyla gönderimini yasaklayan değişikliği onaylamıştır. Ayrıca AB Atık Nakliye Direktifi de iskartaya çıkan ve atık kabul edilen gemilerin gelişmekte olan ülkelere gönderilmesini yasaklamaktadır (EC, 2010:6-7). Oysa Hong Kong Sözleşmesi, söküm işlemini yapacak tesisin lisanslı olması koşuluyla, ihracata ilişkin her hangi bir coğrafi sınırlama öngörmemektedir. Böylece Sözleşme söküm işlemi sirasında ve sonrasında ortaya çıkacak ciddi miktarda tehlikeli atığ tecek, işçi sağlığı ve güvenliği açısından gerekli şartları yerine getirecek kapasiteye sahip olmayan ülkelere bu gemilerin gönderimine ilişkin her hangi bir sinırlama getirmemektedir. Ayrıca bu ülkelerde hali hazırda uygulanmakta olan kıyıda söküm işlemine ilişkin bir yasaklama da söz konusu değildir. Diğer taraftan, Sözleşme'nin öngördügü sertifika ve lisansa dayalı prosedür suistimale ve yozlaşmaya açıtır (Lück, 2010:103).

Kapsam açısından değerlendirdiğimizde ise Basel Sözleşmesi'nin tehlikeli atık kavraminı temel aldığı için tüm gemileri kapsayan bir düzenleme olduğunu söyleyebiliriz. Ayrıca Sözleşme atık yönetiminin tüm aşamalarını, yani atıkların toplanması, nakliyesi, geri kazanımı ve nihai bertarafına ilişkin tüm işlemleri kapsamaktadır. Hong Kong Sözleşmesi ise 500 gross tondan küçük gemileri, savaş ve donanma gemilerini, devlete ait gemileri ve ticari amaçla kullanılmayan gemileri kapsamamaktadır. Oysa Sözleşme'ye dâhil edilmeyen gemilerin söküm işlemlerinin ya da çevre üzerindeki etkilerinin Sözleşme'ye dâhil edilenlerden bir farkı yoktur. Böylesi bir ayrım bizatihi Sözleşme'nin amacına aykırıdır (Bhattacharjee, 2009:222223). Bununla birlikte Hong Kong Sözleşmesi beşikten mezara yaklaşımını benimsemekte ve yeni üretilecek gemiler ile mevcut gemilerin bakım ve onarımında tehlikeli madde kullanımını yasaklamaktadır. $\mathrm{Bu}$, sorunun kaynağında önlenmesi açısından radikal bir ilerlemedir ve Hong Kong Sözleşmesi'nin sorunun çözümüne katk1 sağladığ1 temel noktadır (Bhattacharjee, 2009:221). Ancak Hong Kong Sözleşmesi, söküm sırasında ve sonrasında ortaya çıkan atıkların çevreye duyarlı yönetimi ve bertafıyla ilgili şartlar içermemektedir.

Diğer taraftan, her iki sözleşeme de tarafların sözleşmeye uyumunu artırmak amacıyla kapasitelerinin güçlendirilmesine yönelik teknik ve finansal destek mekanizmaları oluşturma konusunda başarısız kalmaktadır. Gemi sökümü yapan ülkeler genel olarak, gerekli teknik ve altyapısal dönüşümü sağlayacak kapasiteye sahip değillerdir. Bu nedenle işçi sağlığ 1 ve güvenliği ile çevresel korumaya ilişkin standartların yerine getirilmesi konusunda bu ülkelerin kapasitesini güçlendirecek teknik ve finansal destek mekanizmalarına ihtiyaç duyulmaktadır. Ayrıca her iki Sözleşme de tarafların uyumunu denetleme ve izleme konusunda yetersiz kalmakta ve ihlalleri caydırıcı nitelikte yaptırım ve cezalara yer vermemektedir. Gerek Hong Kong Sözleşmesi gerekse Basel Sözleşmesi bu konudaki asıl sorumluluğu taraf devletlere birakmaktadır. Taraf devletler sözleşmelerin uygulaması için gerekli tedbirleri almalı, ilgili yasal çerçeveyi oluşturmalı, izleme ve denetim gibi prosedürleri yerine getirmeli ve ihlalleri caydıracak nitelikte ceza ve yaptırımlar öngörmelidirler (EC, 2010:4-6).

Ancak taraf devletlerin sözleşmeye uyumu, daha öncede ifade edildiği üzere hem istek hem de kapasite meselesidir. Devletlerin her hangi bir sözleşmeyi uygulamaya istekli olması, her şeyden önce ilgili sözleşmenin devletin çıkarına hizmet etmesine ya da en azından çıkarlarına ters düşmemesine bağlıdır (Weiss-Jacobson 1999: 39). Oysa gemi sökümü sorunu devletlerin ekonomik çıkarlarını doğrudan etkileyen bir sorundur. Gelişmiş ülkeler bu yolla hem yüksek söküm maliyetlerinden, hem de teh- 
likeli atık yönetimi maliyetlerinden kurutulmakta ayrıca yüksek risk taşıyan bir faaliyetin olumsuz etkilerini bertaraf etmektedirler. Diğer taraftan, söküm işleminin yapıldığı ülkeler ise bu işten önemli miktarda gelir elde etmekte ve çelik endüstrilerine hammadde sağlamaktadır. Dolayısıyla bu ticaretin yasaklanması ya da sinırlandirılması, sorunun muhatabı olan iki ülke grubunca da tercih edilen bir durum değildir. Aslına bakılırsa Basel ve Hong Kong Sözleşmelerinin bu konuda yeterince güçlü bir çerçeve oluşturamamalarının temel nedeni de budur. Devletler ekonomik çıkarları nedeniyle, sorunun çözümüne katkı sağlayacak güçlü düzenlemeler oluşturulmasına yeterice destek vermemektedir. Zira Hong Kong Sözleşmesi'ni, gemi sökümü yapılan 5 ülkeden sadece Türkiye onaylamıştır. ${ }^{10}$ Sözleşmenin yürürlüğe girebilmesi için en az 15 ülke tarafından onaylanması ve bu ülkelerin ticari gemi filolarının hacminin toplam dünya ticaret filosu hacminin \% 40'ını oluşturması gerekmektedir. Hali hazırda Sözleşme 5 ülke tarafından imzalanmıştır (Fransa, İtalya, Hollanda, Saint Kitts ve Nevis ve Türkiye) ve bu ülkelerin toplamdaki payı \% 10'u bile bulmamaktadır (Mikelis, 2010). Bu nedenle Sözleşme'nin yürürlüğe girmesin bir hayli zaman alacağını söyleyebiliriz.

\section{SONUÇ}

Gemi sökümü sorunu 1980'leden buyana uluslararası toplumun gündeminde olan bir meseledir. Özellikle sivil toplum kuruluşlarının ve medyanın yoğun ilgi gösterdiği sektör, gerek ulusal gerekse uluslararası çapta hazırlanan çok sayıda rapora konu olmuş ve sektörlerle bütünleşen sorunlara dikkat çekilmiştir. Kamuoyunun gemi sökümüne ilişkin ilgi ve kaygısının artması IMO, ILO ve UNEP (Birleşmiş Miletler Çevre Programı) gibi uluslararası örgütlerin, söküm işleminin daha güvenli ve sürdürülebilir bir temelde gerçekleştirmesini sağlamak üzere yol gösterici rehberler hazırlamasını sağlamıştır. $\mathrm{Ne}$ var ki, bu düzenlemeler bağlayıcı nitelik taşımamaktadır. Bu nedenle ilgili sorunla mücadelede uluslararası toplumun elinde temelde iki araç bulunmaktadır. Ancak Basel Sözleşmesi, gemi sökümüne değil, tehlikeli atıkların sınır ötesi taşınımına ilişkin bir düzenleme olduğundan uygulamada boşluk yaratabilmektedir. Geri dönüşüm amacıyla hurda gemi ticaretine Basel Sözleşmesi hükümlerinin uygulanması bir bakıma taraf devletlerin iradesine bağlı bir durumdur. Aslında söküm endüstrisine sahip ülkeler, Sözleşme'nin işçi sağlığı ve güvenliği ile çevrenin korunmasına ilişkin standartlarını yerine getirme konusunda asgari düzeyde de olsa bir çaba göstermektedir. Buna karșın ticaretin kontrolüne ya da sınırlandırılmasına ilişkin şartlara uyum sağlama konusuna isteksizdirler. Bu durum, ister istemez ciddi miktardaki tehlikeli atığın, uygun yönetim imkânlarına sahip olmayan gelişmekte olan ülkelere transferi sorununu devam ettirmektedir. Gerçekten de söküm endüstrisine sahip ülkeler arasında görece en iyi durumdaki ülkelerden biri olan Türkiye de bile sadece bir tek tehlikeli atık bertaraf tesisi bulunmaktadır ve tesisin kapasitesi, ülke ihtiyaçlarını karşılamaktan uzaktır (ÇOB 2007: 186). Söküm amacıyla gelen gemiler doğal olarak bu ülkelerdeki atık yönetimi sorununu daha da artırmaktadır. Diğer taraftan söküm işlemi yapılan ülkelerin tamamında işçi sağlığı ve güvenliğine ilişkin koşullar hala ciddi bir endişe kaynağıdır.

Sorunla doğrudan ilgili düzenleme olan Hong Kong Sözleşmesi ise henüz yürürlükte değildir. Ayrıca sözleşme gemi sökümüyle bütünleşen sağlık, güvenlik ve çevreye ilişkin sorunlara yanit olabilecek yetkinlikte de görülmemektedir. Sözleşme esasa ilişkin yükümlüklerden ziyade prosedürel yükümlülüklere ağırlık vermektedir. Ancak inceleme, sertifika ve lisans gibi prosedürlerin yerine getirilmiş olması, gemi söküm işleminin standartlara uygun şekilde yapılacağını garanti etmemektedir. Bu nedenle hali hazırda iki Sözleşme'nin de söküm endüstrisindeki sorunların çözümüne ciddi bir katkı sağladığını söylemek güçtür. Bu düzenlemeler, kötümser bir bakış açısıyla adalet, eşitlik, insan hakları gibi etik değerler bağlamında uluslararası toplumun soruna kayitsız kala- 
mayacağı yönündeki baskıya cevaben oluşturulan suni çözümler olarak yorumlanabilir. Ancak iyimser bir bakış açıyla bu düzenlemeleri sorunun çözümüne yönelik daha güçlü çabaların bir başlangıcı olarak görmekte mümkündür. Çerçeve sözleşeme niteliği taşıyan her iki düzenleme de ekler ya da değişiklikler yoluyla güçlendirilerek bu konuda ciddi katkılar sağlayabilirler. Ancak buradaki temel mesele sorunun ortaya çıkışına neden olan ekonomik güdülerle baş edebilmektedir. Gelişmiş ülkelerin geri dönüşüm ve tehlikeli atık yönetimi maliyetlerine katlanmasını sağlamak, gelişmekte olan ülkelerin bu sektöre bağımlılıklarını azaltacak yeni ekonomik firsatlar yaratmak kuşkusuz zor ancak daha adil bir çözüm yolu olacaktır.

\section{Notlar}

1 Basel Sözleşmesi'nin tam metnine http://www.basel.int; Hong Kong Sözleşmesi'nin tam metnine http://ec.europa.eu/environment /waste/ships/pdf/Convention.pdf adresinden ulaşılabilir.

2 Dwt (deadweight ton): geminin net ağırlı̆̆ı.

3 Bkz. Sarraf, Maria, Lauridsen, Frank Stuer vd. (2010), Ship Breaking and Recycling Industry in Bangladesh and Pakistan, World Bank.; Judit Kanthak ve Nityanand Jayaraman, (2001) Ships for Scrap III, Steel and Toxic Wastes for Asia: Findings of a Greenpeace Study on Workplace and Environmental Contamination in Alang-Sosiya Ship-breaking Yards, Gujarat, India, Greenpeace Report

15 , http://ban.org/library/ALANG\%202000\%20final. pdf, (22.11.2011).

4 Bkz. Greenpeace, Ships for Scrap V: Steel and Toxic Wastes for Asia: Greenpeace Report on Environmental, Health and Safety Conditions in Aliağa Ship-breaking Yards, 2002; Dokuz Eylül University Institute of Marine Sciences and Technology, The Analysis of Seawater Using in The Cooling System of a Power Plant in The Industrial Zone of Aliağa, Report DBTE-127, 2000; Çalışma ve Sosyal Güvenlik Bakanlığı, Gemi Sökümü Yapılan İsyerlerinde İş Sağllğı ve Güvenliği Proje Denetimi Değerlendirme Raporu, 2005, Ankara; Çalışma ve Sosyal Güvenlik Bakanliğı, Gemi Söküm İşyerlerinde İş Sağhloğ ve Güvenliğgi Teftiş Projesi 2 Genel Değerlendirme Raporu, 2007, Ankara.

5 Bangladeş ve Hindistan'daki söküm alanlarında çalışan iş̧̧ilerin günlük ücreti 1-2 USD'dir. Avrupa Birliği ülkelerinde ise günlük ücret 250 USD (Norveç) ile 13 USD (Bulgaristan) arasında değişmektedir. (EC, 2007a: 6).

6 Bkz. IMO, Guidelines on Ship Recycling, 2003.; ILO, Safety and Health in Ship Breaking: Guidelines for Asian Countries and Turkey, 2003.; Secretary of Basel Convention, Technical Guidelines For The Environmentally Sound Management of The Full and Partial Dismantling Of Ships, 2002.

7 Basel Sözleşmesi'nin Tehlikeli Atıkların Ulusal Tanımı başlıklı 3. maddesi taraf devletlere Basel Sözleşmesi'nin kontrole tabi atık listelerinde yer almasa bile ulusal mevzuatları gereğince tehlikeli 
kabul edilen atıkların ülkelerine girişini yasaklama hakkı tanımaktadır(BS, Mad.3/1). Bu hakkı kullanan taraflar Sözleşme Sekretaryasina gerekli bildirimde bulunacak ve ihracatçı devletler söz konusu atıkların ilgiyi ülkeye ihracın yasaklayacaklardır (BS, Mad.4/1a-b).İthalatçı devlet'in tehlikeli atıkların ve diğer atıklarm ithalini yasaklamadığı $d u$ rumlarda ise ithalatçı devlet söz konusu ithalata yazılı olarak riza göstermediği takdirde Taraflar, tehlikeli atıklarm veya diğer atıklarm ihracın yasaklayacak veya bu ihracat işlemine izin vermeyeceklerdir (BS, Mad.4/1c).

8 Sözleşme metninde atıkların çevreye duyarlı yönetimi kavramı muğlak kalsa da, Sözleşme Sekretaryası tarafından bu amaçla hazırlanan çok sayıda teknik rehber taraf devletler için önemli bir yol göstericidir.

9 Türkiye 2002 yılında Fransiz bayraklı Sea Beirut adlı gemiyi, 2006 yılında ise Hollanda bayraklı Otopan adlı gemiyi bildirimlerinin doğru olmaması sebebiyle yasa dışı ticaret kabul ederek geri göndermiştir.

102009 Hong Kong Sözleşmesi'ni imzalayan devletler Fransa, Ittalya, Hollanda, Saint Kitts ve Nevis ve Türkiye'dir.

\section{KAYNAKÇA}

Andersen, Aage Bjørn (2001), Worker Safety in the Ship-breaking Industries, ILO, Geneva.

Bhattacharjee, Saurabh (2009), "From Basel To Hong Kong: International Environmental Regulation of Ship-Recycling Takes One Step Forward And Two Steps Back", Trade, Law and Development,Volume 1, Issue 2, ss. 193-230.

Christensen, Ingrid (2010), "Ship Recycling from an ILO Perspective", Secretariat of The Basel Convention Ship Recycling Technology \& Knowledge Transfer Workshop, 14-16 July, Turkey. http:/ / archive.basel.int/ships/ktw/in dex.html, (22.10.2011).

CIEL - The Center For International Environmental Law (2011), Shipbreaking and The Basel Convention: Analysis of The Level of Control Established Under The Hong Kong Convention. http:/ / www.ciel.org/Publications/Shi pbreaking_22Apr11.pdf, (13.11.2011).

Çeviker, Ersin (2010) "Ship Recycling in Turkey The Industry Perspective", Secretariat of The Basel Convention Ship Recycling Technology \& Knowledge Transfer Workshop, 14-16 July, Turkey. http://archive.basel.int/ships/ktw/in dex.html, (22.10.2011).

ÇOB - Çevre ve Orman Bakanlığ1 (2007), Türkiye Çevre Durum Raporu, Ankara.

ÇSGB - Çalışma ve Sosyal Güvenlik Bakanlığ 1 (2007), Gemi Söküm İsyyerlerinde İş Sağlığı ve Güvenliği Teftiş Projesi - 2 Genel Değerlendirme Raporu, Ankara. 
DDK - Devlet Denetleme Kurumu (2008), Tersanecilik Sektörü ile İş Sağlığ1 ve Güvenliği Açısından Tuzla Tersaneler Bölgesinin İncelenmesi ve Değerlendirilmesi Hakkında Araştırma ve İnceleme Raporu. http://www.tccb.gov.tr/ddk/ddk25.p df (08.12.2011).

EC - Commission of The European Communities (2007a), Green Paper On Better Ship Dismantling, Brussels.

EC (2007b), Ship Dismantling and Pre-cleaning of Ships Final Report, http:/ / ec.europa.eu/environment/wa ste/ships/pdf/ship_dismantling_report.pdf, (18.12.2011)

EC (2008), An EU Strategy for Better Ship Dismantling, Brussels.

EC (2010), An Assessment of the Link Between the IMO Hong Kong Convention for the Safe and Environmentally Sound Recycling of Ships, the Basel Convention and the EU Waste Shipment Regulation, Brussels. http:/ / ec.europa.eu/environment/wa ste/ships / pdf/report0310.pdf, (28.11.2011).

ILO (2003), Safety and Health in Ship-breaking: Guidelines for Asian Countries and Turkey, Geneva.

Jacobson, Harold K., Weiss, Edith Brown (1997), “Compliance with International Environmental Accords: Achievements and Strategies", International Governance on Environmental Issues, (ed.), Mats Rolén, Helen Sjöberg and Uno Svedin, Kluwer Academic Publishers, Dordrecht, ss. 78-110.

Kummer, Katharina (1992), "The International Regulation of Transboundary Traffic in Hazardous Wastes: The 1989 Basel Convention", The International and Comparative Law Quarterly, Vol. 41, No. 3, ss. 530-562.
Küçükgül, Enver Yaser., Güneş, Fatma (2007), "Gemi Sökümü ve Tehlikeli Atık Yönetimi", 7. Ulusal Çevre Mühendisliği Kongresi, 24-27 Aralık 2007, İzmir, ss. 318-326.

Lawrence, Peter (1998), "Negotiating of a Protokol on Liability and Compensation For Damage Resulting From Transboundary Movements of Hazardous Wastes and Their Disposal", RECIEL, Vol.7, Issue 3, ss. 249-255.

Lück, Nele Matz (2010), "Safe and Sound Scrapping of Rusty Buckets? The 2009 Hong Kong Ship Recycling Convention", RECIEL, 19/1, ss. 95-103.

Mikelis, Nikos (2010) Introduction To The Hong Kong Convention And Its Requirements, Secretariat of The Basel Convention Ship Recycling Technology \& Knowledge Transfer Workshop, 14-16 July, Turkey. http:/ / archive.basel.int/ships/ktw/in dex.html, (22.10.2011).

Moen, Amy E. (2008), “Breaking Basel: The Elements of the Basel Convention and its Application to Toxic Ships", Marine Policy, 32. ss. 1053-1062.

Neşer, Gökdeniz; Ünsalan, Deniz, vd. (2008), "The Shipbreaking Industry in Turkey: Environmental Safety, Health Issues", Journal of Cleaner Production, 16, ss. 350-358.

Öztürk, Ayşe (2010), Employers' Health \& Safety Responsibilities, Secretariat of The Basel Convention Ship Recycling Technology \& Knowledge Transfer Workshop, 14-16 July, Turkey. http:/ / archive.basel.int/ships/ktw/in dex.html, (22.10.2011).

Sand, Peter H. (1992), The Effectiveness of International Environmental Agreements, Grotius Publications, Cambridge. 
SBC - Secretary of Basel Convention (1995), Report of the Third Meeting of the Conference of the Parties to the Basel Convention, http://www.basel.int/ meetings/cop/cop1-4/cop3repe.pdf (22.10.2011).

SBC (2004), Report of the Seventh Meeting of the Conference of the Parties to the Basel Convention, http:/ / www.basel.int/meetings/cop/ cop7/docs/33eRep. pdf (22.10.2011).

SBC (2008), The Basel Convention At a Glance, http:/ / www.basel.int/convention/ bc_glance.pdf (07.10.2011).

UNCTAD - United Nations Conferance on Trade and Development (2010), Review of Maritime Transport, United Nations Publications.

Vardar, Erdem (2004), “Türkiye'de ve Dünyada Gemi Söküm Sanayi ve Çevre", Gemi Mühendisliği ve Sanayimiz Sempozyumu, 24-25 Aralık 2004, ss. 322333.

Weiss, Edith Brown, Jacobson, Harold K. (1999), "Getting Countries to Comply With International Agreements", Environment, 41: 6, ss. 16-45.

Wettestad, Jorgen (1999), Designing Effective Environmental Regimes: The Key Conditions, Edward Elgar Publishing, Cheltenham, UK.

Young, Oran R., Demko, George J. (1996), "Improving the Effectiveness of International Environmental Governance Systems", Global Environmental Change and International Governance, (ed.) Oran R. Young, George J. Demko and Kilaparti Ramakrishna, University Press of New England, Hanover, ss. 229-246. 